\title{
Geohazard studies offshore the Faroe Islands: slope instability, bottom currents and sub-seabed sediment mobilisation
}

\author{
Tove Nielsen and Antoon Kuijpers
}

Prior to the 1990s only few geological investigations of the seabed and the shallow geology around the Faroe Islands had been undertaken (Waagstein \& Rasmussen 1975; Nielsen et al. 1981). However, in the 1990s marine geological and in particular seismic investigations were markedly intensified. Since 1993 several studies on the structure of the Faroe Islands margin and seafloor processes have been funded by the European Union, namely the ENAM (European North Atlantic Margin) project I and II (1993-1999) and the STRATAGEM (Stratigraphy of the Glaciated European Margin) project (2000-2003), and these have provided sig-

nificant new information on the mechanisms shaping the Faroe Islands margin (e.g. Boldreel et al. 1998; Kuijpers et al. 1998a; Nielsen \& van Weering 1998; van Weering et al. 1998). Due to the expertise and regional geological knowledge obtained during these projects the Geological Survey of Denmark and Greenland (GEUS) became involved in socalled 'geohazard' seabed studies of the Faroe-Shetland Channel in 1997. These investigations were financed by the petroleum industry that had begun to show significant interest in exploration of the Faroe-Shetland Channel area. The studies focused on possible natural risks that would affect

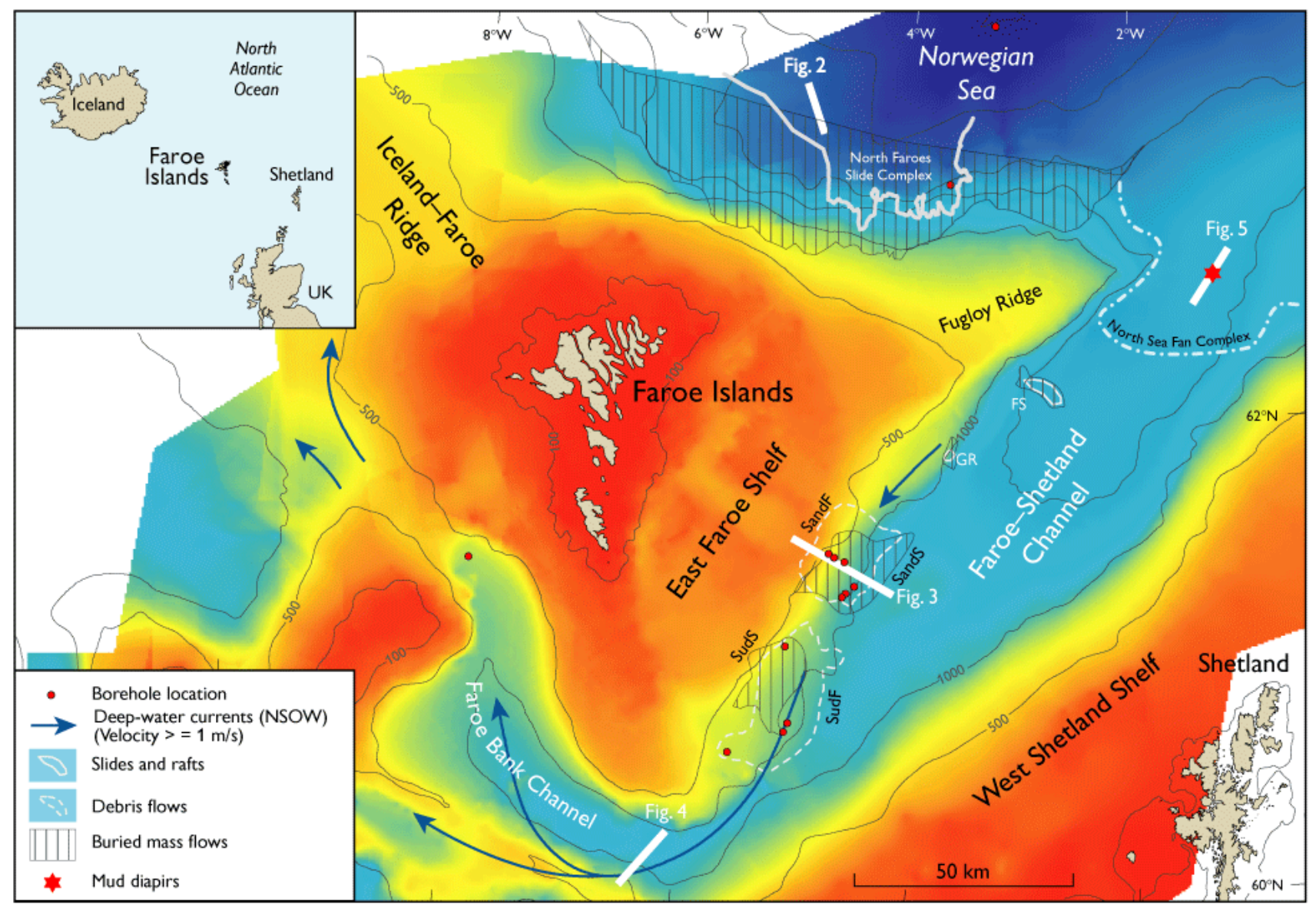

Fig. 1. Overview of the Faroe Platform area with locations of major mass flow deposits, the pathway of high-energy Norwegian Sea overflow water (NSOW), and location of the mud diapirs at the northern entrance of the Faroe-Shetland Channel. FS, FOIB slide; GR, GEM raft; SandF, Sandoy fan; SandS, Sandoy slump; SudF, Suðuroy fan; SudS, Suðuroy slump. 


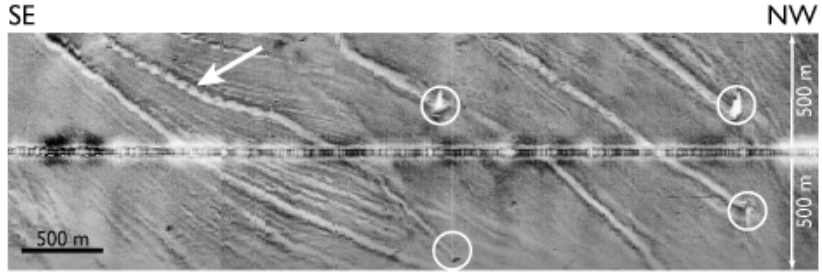

$2300 \mathrm{~m}$

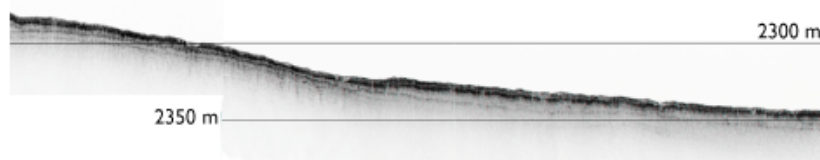

Fig. 2. Deep-tow side-scan sonar record and sub-bottom profile from the trail mark area downslope of the main slump scar in the mass flow area north-east of the Faroe Islands (see Fig. 1). The sonograph shows a large number of outrunner block tracks of varying width, with several blocks (circles) at the ends of their respective tracks. Crossing slide paths are also observed. Arrow indicates markedly irregular pattern of some tracks. From Kuijpers et al. (2001).

submarine structures, such as slope instability and strong bottom currents, and included both shallow seismic data acquisition and sediment core analyses. Most of the work at sea was undertaken with the Russian research vessel Prof. Logachev, and carried out within the framework of the international, UNESCO-supported 'Training-Through-Research' (TTR) programme co-ordinated by Moscow State University, Russia. Since 1997, more than three million DKK have been granted for various projects and this work has been documented in 14 classified reports. This paper presents some of the main results from these 'geohazard' studies, in particular with respect to the sediment instability affecting the western flank of the Faroe-Shetland Channel, the occurrence of very strong bottom currents in the channel, and the newly discovered mud diapirs at the northern entrance of the channel (Fig. 1).

\section{Material and methods}

Seismic data acquisition was carried out with a $100 \mathrm{kHz}$ airgun and a 6-channel streamer to map subbottom structures. Seismic profiling was carried out in combination with a 10 $\mathrm{kHz}$ long-range $(2 \times 6 \mathrm{~km})$ side-scan sonar for obtaining information on seabed surface sediment and topography. In selected areas a higher resolution of the seabed features was necessary, and a deep-towed side-scan sonar was deployed, operating at 30 or $100 \mathrm{kHz}$ with ranges of $2 \times 1000 \mathrm{~m}$ and $2 \times 350 \mathrm{~m}$, respectively. The latter device was also equipped with a $5 \mathrm{kHz}$ subbottom profiler, whereas during all survey activities another, hull-mounted subbottom profiler was routinely operated. Bottom samples were retrieved with a 6-m gravity corer, a box corer, and a large video-controlled grab. In addition, underwater video was deployed. After retrieval of the sediment cores, the cores were described and magnetic susceptibility measurements were carried out on board. Selected samples were investigated using a microscope to determine mineral and microfossil content. After the cruise more extensive core studies were made, and sediments were dated using the AMS ${ }^{14} \mathrm{C}$ method.

\section{Slope instability}

Prior to of the 'geohazard' studies, mass flow deposits had not been reported from the western flank of the Faroe-Shetland Channel. In contrast, a major slide complex was known to extend over most of the north-eastern Faroe Islands margin (Fig. 1). Seismic studies carried out in the latter area during the ENAM project demonstrated that large-scale slumping and sliding had affected the middle and lower slopes below $1500 \mathrm{~m}$ water depth since the Miocene (Nielsen \& van Weering 1998; van Weering et al. 1998). High-resolution side-scan sonar surveying in the area downslope of the main, c. $300 \mathrm{~m}$ high headwall, where water depth is about $2300 \mathrm{~m}$, demonstrated the presence of a large number of downslopetrending tracks on a low slope gradient, locally displaying cross patterns, and occasionally a markedly irregular pattern (Fig. 2). At the termination of the tracks, outrunner blocks of sediment were observed, up to $18 \mathrm{~m}$ high, and with a maximum length of $70 \mathrm{~m}$. Some of the blocks were found at a distance of up to $25 \mathrm{~km}$ from the initial mass flow terminus at the main headwall. The sub-bottom profiles in the trail-mark area indicate that most of the tracks have been filled with transparent sediment acoustically comparable to the Holocene hemipelagic surface unit, and thus may have an age older than Holocene.

At the start of the studies of the western flank of the Faroe-Shetland Channel, it soon became evident that slope instability and associated mass flow had also occurred in this area. Seismic evidence (Fig. 3) clearly shows that these processes have taken place repeatedly since late Pliocene time. Within this context, it should be noted that no evidence has been found for any major mass-wasting activity having occurred subsequent to the early Holocene sea level rise (Kuijpers et al. 2001); i.e. during the past c. 7000 years the Faroe Islands margin appears to have been generally stable.

\section{High-energy bottom current environments}

Export of deep waters formed in the North Atlantic occurs via two major gateways: one between Greenland and Iceland and one between Iceland and Scotland (e.g. Dickson et al. 1990). Sediment core studies have demonstrated that these 
Fig. 3. Single-channel airgun profile from the western flank and basin of the Faroe-Shetland Channel and a schematic interpretation (bottom) showing unit of presumably late Pliocene - early Pleistocene age. the presence of a large mass flow

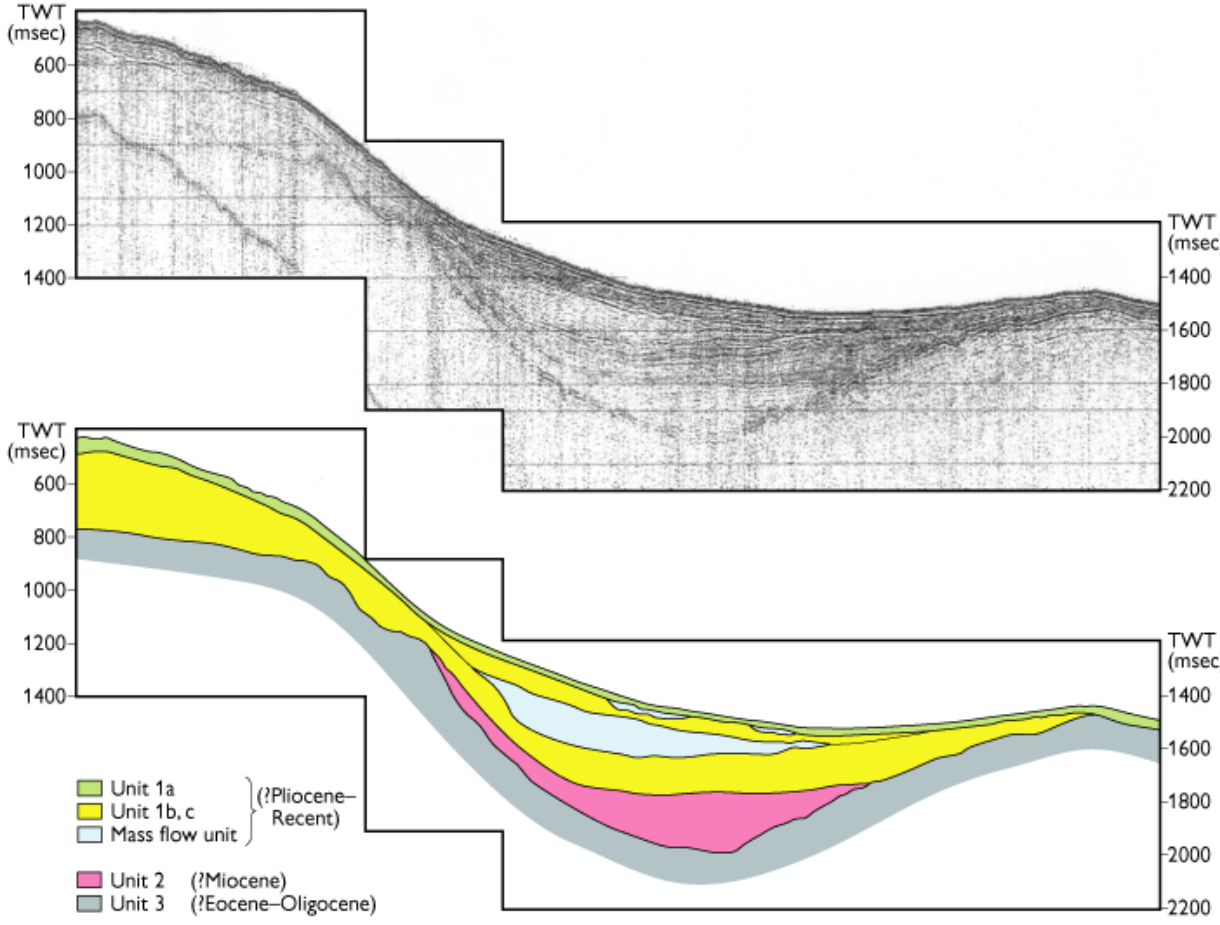

overflow currents were generally reduced or ceased during cold (stadial) climate periods, relative to interstadial and particularly interglacial conditions (e.g. Kuijpers et al. 1998b). Noteworthy in this context is the recent observation in the Faroe-Shetland Channel of a decreasing overflow since 1950 (Hansen et al. 2001). For the purpose of providing information on the high-energy overflow current environments along the Faroe-Shetland gateway, an inventory of current-induced bedforms detected by side-scan sonar was undertaken, which revealed the flow path where near-bottom current speed reaches around $1.0 \mathrm{~m} / \mathrm{s}$ (Kuijpers et al. 2002). For comparison, supplementary information from actual current meter measurements has been added in order to determine whether the bedforms recorded (Fig. 4) could be relict features, or can be considered to be in equilibrium with the recent current regime. Our knowledge of overflow processes, which were previously based only on information from current meter stations and ship-borne hydrographic sections, has thus been extended and a regional overview of the areas most intensively influenced by the overflow currents has been obtained.

\section{Sub-seabed sediment mobilisation}

Submarine mud volcanoes, or diapirs, can range in size between 0.5 and $800 \mathrm{~m}$ high. Two main mechanisms are considered to lead to the formation of mud diapirism, i.e. high sedimentation rates and/or lateral tectonic compression. Both mechanisms can result in over-pressure of a mobile sediment layer at sub-bottom depth. In the mid-1990s mound features were observed immediately east of the Fugloy Ridge (see Fig. 1) by the British Geological Survey (BGS), and were reported as possible cold-water coral mounds. Further high-

Fig. 4. Deep-tow side-scan sonar record of Norwegian Sea overflow water (NSOW)-induced sandwaves at the southern end of the Faroe-Shetland Channel. Water depth is 1100-1200 m. From Kuijpers et al. (2002).

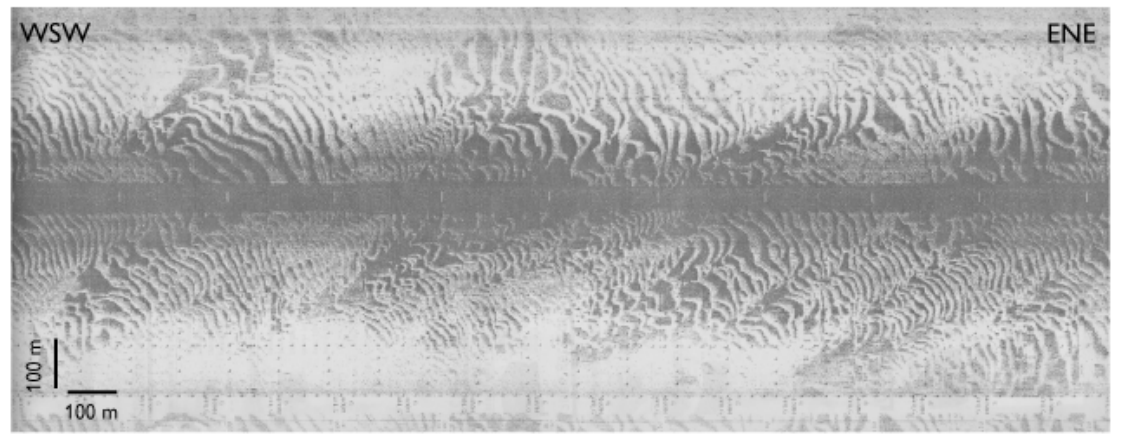




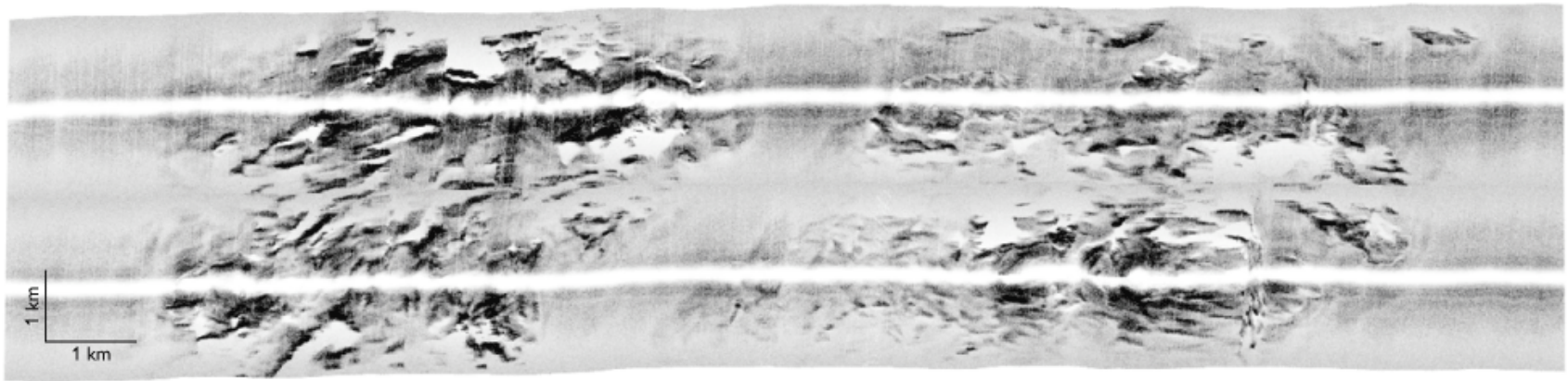

Fig. 5. Mosaic image of deep-tow side-scan sonar records of the mud diapir area at the northern entrance of the Faroe-Shetland Channel. Water depth is $1600-1700 \mathrm{~m}$. From Nielsen et al. (2002).

resolution seismic work by BGS and the Royal Netherlands Institute for Sea Research (NIOZ) revealed, however, that the mounds were most likely mud-diapirs, an interpretation later supported by a TOBI side-scan sonar survey carried out by the Southampton Oceanography Centre (SOC). During the 2002 TTR-cruise with R/V Prof. Logachev GEUS made a detailed study of the mounds at the northern entrance of the Faroe-Shetland Channel (Fig. 5).

The results of this work confirm that the mound structures can be classified as mud diapirs originating from subsurface sediment mobilisation. This sediment mobilisation is probably due to the excessive load of dense, glacigenic sediments of the North Sea Fan deposited on top of low-density (Miocene) diatomaceous ooze. Several stages of maturity have been observed: (1) an initial stage where the diapirs do not pierce the seabed, (2) a young (up to $50 \mathrm{~m}$ high) stage displaying a marked relief, and (3) an up to $100 \mathrm{~m}$ high, mature stage where the diapirs have a smoother appearance. Preliminary results from AMS ${ }^{14} \mathrm{C}$ dating of sediment cores collected from the diapirs suggest an episode of major activation of the diapirs around the time of the Last Glacial Maximum (LGM).

\section{Acknowledgements}

The studies were supported by the Faroese offshore consortium GEM (now FOIB) and the European ENAM-II and STRATAGEM projects. The contributions from colleagues at GEUS, NIOZ, BGS and the TTR-programme are gratefully acknowledged.

\section{References}

Boldreel, L.O. \& Andersen, M.S. 1993: Late Paleocene to Miocene compression in the Faeroe-Rockall area. In: Parker, J.R. (ed.): Petroleum geology of Northwest Europe: proceedings of the 4th conference, 1025-1034. London: The Geological Society.

Boldreel, L.O., Andersen, M.S. \& Kuijpers, A. 1998: Neogene seismic facies and deep-water gateways in the Faeroe Bank area, NE Atlantic. Marine Geology 152, 129-140.

Dickson, R.R., Gmitrowicz, E.M. \& Watson, A.J. 1990: Deep water renewal in the northern North Atlantic. Nature 344, 848-850.

Hansen, B., Turell, W.R. \& Østerhus, S. 2001: Decreasing overflow from the Nordic Seas into the Atlantic Ocean through the Faroe Bank Channel since 1950. Nature 411, 927-930.

Kuijpers, A., Andersen, M.S., Kenyon, N.H., Kunzendorf, H. \& van Weering, T.C.E. 1998a: Quaternary sedimentation and Norwegian Sea overflow pathways around Bill Bailey Bank, northeastern Atlantic. Marine Geology 152, 101-127.

Kuijpers, A., Troelstra, S.R., Wisse, M., Heier Nielsen, S. \& van Weering, T.C.E. 1998b: Norwegian Sea overflow variability and NE Atlantic surface hydrography during the past 150,000 years. Marine Geology 152, 75-99.

Kuijpers, A., Nielsen, T., Akhmetzhanov, A., De Haas, H., Kenyon, N.H. \& van Weering, T.C.E. 2001: Late Quaternary slope instability on the Faeroe margin: mass flow features and timing of events. Geo-Marine Letters 20, 149-159.

Kuijpers, A., Hansen, B., Hühnerbach, V., Larsen, B., Nielsen, T. \& Werner, F. 2002: Norwegian Sea overflow through the Faroe-Shetland gateway as documented by its bedforms. Marine Geology $\mathbf{1 8 8}$, $147-164$.

Nielsen, T. \& van Weering, T.C.E. 1998: Seismic stratigraphy and sedimentary processes at the Norwegian Sea margin northeast of the Faeroe Islands. Marine Geology 152, 141-157.

Nielsen, T.H., Waagstein, R., Rasmussen, J. \& Larsen, B. 1981: Marine seismic investigation of the shelf around the Faeroe Islands. Danmarks Geologiske Undersøgelse Årbog 1981, 101-109.

van Weering, T.C.E., Nielsen, T., Kenyon, N.H., Akentieva, K. \& Kuijpers, A. 1998: Sediments and sedimentation at the NE Faeroe continental margin; contourites and large-scale sliding. Marine Geology 152, 159-176.

Waagstein, R. \& Rasmussen, J. 1975: Glacial erratics from the seafloor south-east of the Faeroe Islands and the limit of glaciation. Annales Societatis Scientarum Faeroensis 23, 101-119.

\section{Authors' address}

Geological Survey of Denmark and Greenland, Øster Voldgade 10, DK-1350 Copenhagen K, Denmark. E-mail: tni@geus.dk 